University of Nebraska - Lincoln

DigitalCommons@University of Nebraska - Lincoln

9-1979

\title{
Morphology and Distribution of Petiolar Nectaries in Ipomoea (Convolvulaceae)
}

Kathleen H. Keeler

University of Nebraska - Lincoln, kkeeler1@unl.edu

Robert B. Kaul

University of Nebraska - Lincoln, rkaul1@unl.edu

Follow this and additional works at: https://digitalcommons.unl.edu/bioscifacpub

Part of the Biodiversity Commons, Botany Commons, Ecology and Evolutionary Biology Commons, and the Plant Biology Commons

Keeler, Kathleen H. and Kaul, Robert B., "Morphology and Distribution of Petiolar Nectaries in Ipomoea (Convolvulaceae)" (1979). Faculty Publications in the Biological Sciences. 276.

https://digitalcommons.unl.edu/bioscifacpub/276

This Article is brought to you for free and open access by the Papers in the Biological Sciences at DigitalCommons@University of Nebraska - Lincoln. It has been accepted for inclusion in Faculty Publications in the Biological Sciences by an authorized administrator of DigitalCommons@University of Nebraska - Lincoln. 


\title{
MORPHOLOGY AND DISTRIBUTION OF PETIOLAR NECTARIES IN IPOMOEA (CONVOLVULACEAE) ${ }^{1}$
}

\author{
Kathleen H. Keeler and Robert B. Kaul \\ School of Life Sciences, University of Nebraska, Lincoln, Nebraska 68588
}

\section{A B S T R A C T}

\begin{abstract}
The distribution of petiolar nectaries in 24 species of Ipomoea was investigated. Petiolar nectaries were found on 12 species ( 8 new reports, 4 confirmations of previous reports) and quoted from the literature as being found on 3 other species; they were absent from 9 species investigated. The structure of petiolar nectaries in the genus ranges from simple beds of superficial nectar-secreting trichomes ( 1 species), to slightly recessed "basin nectaries"' (8 species), to "crypt nectaries," which are structurally the most complex extrafloral nectaries known ( 3 species). (Structures were not determined for 3 species.) Petiolar nectaries are present in all subgenera, but all crypt nectaries occur in the same section (Eriospermum). Species with extrafloral nectaries tend to be perennial; species lacking extrafloral nectaries tend to be annual. There is no relationship between temperate or tropical habitat and presence of nectaries.
\end{abstract}

DESPITE recent interest in extrafloral nectaries (EFNs) (Bentley, 1977a; Elias, 1979) there is much that is not known about their taxonomic and ecological distributions. Extrafloral nectaries are nectar-producing glands on a plant that do not function in pollination. A number of studies have suggested that EFNs have an important ecological role: they attract insects which then defend the plant by their activities in repelling or preying on herbivores (Elias and Gelband, 1975; Bentley, 1976, 1977a,b; Keeler, 1977; Schemske, 1978; Tilman, 1978; Inouye and Taylor, 1979; Pickett and Clark, 1979). This important ecological function would suggest that for different species, the selection on this character should change. Thus, EFNs should be rather variable in relatively closely related taxa which are subject to different selective pressures. At present so little is known about the ecology of EFNs that it is difficult to predict how environments select differently on them. It is, however, possible to ask if EFNs are variable within related taxa, and if any correlations with the variation can be detected.

Extrafloral nectaries are often present in some members of a genus and absent from others (e.g., Ipomoea, Helianthus, Andropogon), and variation within a species has been noted, e.g., in $R u$ -

\footnotetext{
${ }^{1}$ Received for publication 28 December 1978; revision accepted 2 May 1979.

We wish to thank D. F. Austin for his advice and hospitality to K.H.K., and for verifying the identification of the species studied. We thank him for the use of his unpublished studies. Seeds were kindly provided by A. DerMarderosian, C. R. Gunn, and D. F. Austin. K. W. Lee carried out the SEM studies. G. Drohman has been responsible for maintaining the plants in the face of vigorous insect attack.

Partial support (K.H.K.) by NSF SER 77-06931.
}

bus flagellaris (Rosaceae), (Gleason, 1963) and Bixa orellana (Bixaceae) (Bentley, 1977b). Variation within families appears to be the rule (Zimmermann, 1932; Bentley, 1977a; Elias, 1979).

The genus Ipomoea (Convolvulaceae) consists of some 500 species (Austin, 1975) with such common representatives as morning glory, moon vine, cypress vine and sweet potato. The species are chiefly tropical, herbaceous, and vining, but there are temperate, woody, and arborescent species. Ipomoea includes species which have and lack EFNs on both the petioles and sepals. Structural variation in the EFNs of Ipomoea has been recognized for a long time (Poulsen, 1877; Gardiner, 1887; Rao, 1930; Zimmermann, 1932; Napp-Zinn, 1973). The EFNs of a few species of Ipomoea have been described morphologically (Poulsen, 1877; Gardiner, 1887; Ewart, 1895), and the ecological function of some species has been investigated (Nieuwenhuis, 1907; van der Pijl, 1954; Keeler, 1977).

This paper reports the structure and distribution of petiolar nectaries in 24 New World species of Ipomoea, representing all three subgenera and 7 of the 9 sections of the genus as defined by Austin (1975; pers. comm.). It greatly expands previous work on the distribution of nectary types in the genus and for the first time considers species lacking petiolar nectaries. We further attempt to interpret this distribution in terms of phylogeny and ecology.

MATERIALS AND METHODS-Plants of as many species of Ipomoea as possible were assembled from a variety of seed sources. These were grown in the greenhouse at the University of Nebraska, Lincoln, and presence of petiolar nec- 
TABLE 1. Relationship of presence of petiolar nectaries in Ipomoea to systematics of the genus

\begin{tabular}{|c|c|c|c|}
\hline & $\begin{array}{l}\text { Petiolar } \\
\text { nectary }\end{array}$ & $\begin{array}{l}\text { Type of } \\
\text { nectary }\end{array}$ & $\begin{array}{c}\text { Previous } \\
\text { report }\end{array}$ \\
\hline \multicolumn{4}{|l|}{ Subgenus Ipomoea } \\
\hline \multicolumn{4}{|l|}{ Section Pharbitis } \\
\hline I. hederacea Jacq. & - & & \\
\hline I. indica (Burm. $f$. ) Merrill & + & basin & \\
\hline I. nil (L.) Roth & - & & \\
\hline I. purpurea (L.) Roth & - & & \\
\hline \multicolumn{4}{|l|}{ Subgenus Eriospermum } \\
\hline \multicolumn{4}{|l|}{ Section Eriospermum } \\
\hline I. bonariensis Hook. & + & crypt & $\mathrm{f}$ \\
\hline I. carnea Jacq. & + & crypt & d,e,g \\
\hline I. horsfalliae Hook. & + & "especially simple" & b \\
\hline I. leptophylla Torr. & + & $\begin{array}{l}\text { superficial } \\
\text { nectaries }\end{array}$ & \\
\hline I. mauritiana Jacq. & + & crypt & c \\
\hline I. macrorhiza Michx. & + & not determined & \\
\hline I. pandurata (L.) Meyer & - & & \\
\hline \multicolumn{4}{|l|}{ Section Erpipomoea } \\
\hline I. pes-caprae (L.) R.Br. & + & basin & \\
\hline I. stolonifera (Cyrill.) Gmelin & - & & \\
\hline \multicolumn{4}{|l|}{ Subgenus Quamoclit } \\
\hline \multicolumn{4}{|l|}{ Section Batatas } \\
\hline I. batatas (L.) Lam. & + & basin & a \\
\hline I. lacunosa $\mathrm{L}$. & - & & \\
\hline I. tiliacea (Willd.) Choisy & - & & \\
\hline I. trichocarpa Ell. & + & not determined & \\
\hline I. triloba $\mathrm{L}$. & + & basin & \\
\hline \multicolumn{4}{|l|}{ Section Orthipomoea } \\
\hline I. cairica (L.) Sweet & + & basin & \\
\hline I. tricolor Cav. & + & basin & \\
\hline \multicolumn{4}{|l|}{ Section Quamoclit } \\
\hline I. coccinea $\mathrm{L}$. & - & & \\
\hline I. quamoclit $\mathrm{L}$. & - & & \\
\hline \multicolumn{4}{|l|}{ Section Calonyction } \\
\hline I. alba $\mathrm{L}$ & + & basin & a \\
\hline I. turbinata Lag. & + & basin & a \\
\hline
\end{tabular}

Systematics after Austin (1975; 1977b; pers. comm.)

Not represented: Subgenus Ipomoea, Section Ipomoea and Subgenus Quamoclit, Section Exogonium.

Not seen by us: I. bonariensis, I. horsfalliae, I. mauritiana.

${ }^{\mathrm{a}}$ Poulsen (1877); ${ }^{\mathrm{b}}$ Gardiner (1887); ${ }^{\mathrm{c}}$ Ewart (1895); ${ }^{\mathrm{d}}$ Nieuwenhuis (1907); ${ }^{\mathrm{e}}$ Spegazzini (1923); ${ }^{\mathrm{f}}$ Rao (1930); ${ }^{\mathrm{g}}$ Leal (1974).

taries was determined. Any species of Ipomoea encountered in the field was also investigated for the presence of EFNs.

The presence of nectaries was investigated by using light and scanning electron microscopy (SEM). Tissues were preserved either in $5 \%$ glutaraldehyde, $2-5 \%$ quinoline sulfate or $50 \%$ ethanol, and cleared in $5 \% \mathrm{NaOH}$, for approximately a week, at $60 \mathrm{C}$, rinsed, and observed in lactic acid. Tissues for electron microscopy were dehydrated, critical-point dried, and coated with gold-palladium.

Presence of nectar was confirmed with Clinistix (Ames) test strips. These are sensitive to 0.1 $\mathrm{g} / \mathrm{ml}$ glucose, which produces a color change.
When possible, plants were observed in the field for visits from nectar-feeding insects, especially ants, wasps, and flies. For all species, these lines of evidence for the presence of EFNs gave mutually consistent results.

References to Ipomoea species in the taxonomic literature were carefully checked for notations of petiolar nectaries (House, 1908; O'Donell, 1959a,b,c, 1960; Matuda, 1964; Shinners, 1970; Gunn, 1972; Austin, 1975, 1977b). It was sometimes possible to find published reports of the presence of EFNs, but it was never possible to determine their absence from the literature.

Plants reported in the literature as having 
EFNs, but that were not seen by us, are included in the results, but the source is always noted. They are included because they provide additional information. However, they artificially increase the apparent frequency of EFNs in the genus because negative data cannot be obtained from the literature.

RESUlTs-Species in the genus Ipomoea may have EFNs on the petioles or on the sepals. Only petiolar nectaries will be considered here; a comparable study of sepal nectaries is in progress. When present, there is a pair of petiolar nectaries or nectary fields on opposite sides of the petiole at its junction with the leaf blade, or slightly up the midrib. These function in immature leaves, through the time the leaf opens and expands to full size. Generally they cease producing nectar shortly after the leaf reaches maturity.

The distribution of petiolar nectaries in $24 \mathrm{Ip}$ omoea species is given in Table 1 . Petiolar nectaries are present on 15 species, 8 of which are new reports, and 4 are confirmations of previous reports. Three species not seen by us were reported in the literature as having petiolar nectaries. Nine of the species seen lack petiolar nectaries.

Light microscopy and SEM of the petiolar nectaries of Ipomoea species show a range of structures, an observation made previously by Poulsen (1877), Gardiner (1887), Rao (1930), Zimmermann (1932), and Napp-Zinn (1973). In 9 species, petiolar nectaries are completely absent, a condition not mentioned by previous workers. In one species we found exposed nectar-secreting trichomes acting as functional nectary; we call these "superficial nectaries." Eight species were found to have nectaries in which one or several nectar-secreting trichomes lie in slightly recessed, irregular depressions; these we call "basin nectaries." Zimmermann (1932) classified the petiolar nectaries of some of the species we studied (e.g., I. batatas) as "Grubennektarien." The most complex type of nectary, found in 3 species, consists of recessed chambers filled with secretory trichomes, connected to the surface only by a duct. These were termed "Hohlnektarien" by Zimmermann; we refer to them as "crypt nectaries."

All species studied by us have capitate tri- chomes (Fig. 1-7) and in all, including those which lack petiolar nectaries, these trichomes are scattered on the surface of the leaf and in some cases are overlain by longer, linear hairs (Fig. 1, 2). Most superficial trichomes are nonsecretory.

In one species, Ipomoea leptophylla, capitate trichomes apparently identical to those common on the plant surface secrete nectar (Fig. 3). These glandular trichomes form a superficial nectary and are quite attractive to nectar-feeding insects (Keeler, in press).

Ipomoea batatas, sweet potato, shows the second level of complexity of nectar-producing structures: basin nectaries. In these, nectar-secreting trichomes are crowded into basins of quite variable shape and size (Fig. 5-9). The basin nectaries vary in depth, with some of the larger ones expanding into distinct chambers below the leaf surface. Each secretory trichome within the basin consists of a basal cell in the epidermis, a single stalk cell, and a head of 4-9 secretory cells (Fig. 9). Neither these nectaries nor any of the other petiolar nectaries in the genus have direct vascularization. Basin nectaries may occur as groups of 2 or more on the petiole. Nectaries of this species were described by Poulsen (1877).

Essentially similar structures (irregular, slightly recessed basins packed with nectar-secreting trichomes) exist in I. alba, I. cairica, I. indica, I. pes-caprae, I. tricolor, I. triloba and I. turbinata. Ipomoea pes-caprae has red pigmentation around the rim of its basin nectaries on a green petiole. Ipomoea turbinata also has red nectaries, but the petiole is red.

Basin nectaries were noted for I. muricata ( $I$. turbinata) by Poulsen (1877), and for I. cicatricosa Bak. from Africa and I. bona-nox (I. alba) by Zimmermann (1932). Gardiner (1887) probably describes basin nectaries for I. horsfalli $(=I$. horsfalliae Hook.) when he states that they have an "especially simple structure."

Ipomoea carnea possesses the most complex extrafloral nectary structure known in the genus. The nectary is sunken in the cortex and opens by a narrow orifice in a raised, almost circular mound that is devoid of the hairs which are so abundant on the leaf (Fig. 4, 10). The mound is visible to the naked eye (Fig. 11), and nectar production is copious (Fig. 12). A wide duct leads

Fig. 1-7. 1. Scanning electron micrograph (SEM) of petiole of Ipomoea purpurea. No extrafloral nectary is present. Note presence of capitate trichomes. $\times 100$. 2. SEM of lower petiole of $I$. carnea. Capitate trichomes are non-glandular. $\times 140$. 3. SEM of nectar-secreting trichomes of $I$. leptophylla early leaves. $\times 240$. 4. SEM of opening of crypt nectary, surface of petiole of $I$. carnea. $\times 100$. 5. SEM of basin nectaries of petiole of $I$. batatas. Capitate nectar-secreting trichomes lie in depressions of variable size and shape. $\times 60$. 6. Closer SEM of nectar-secreting trichomes of $I$. batatas in a basin nectary. $\times 240$. 7. SEM of basin nectaries of the petiole of Ipomoea alba. $\times 100$. 


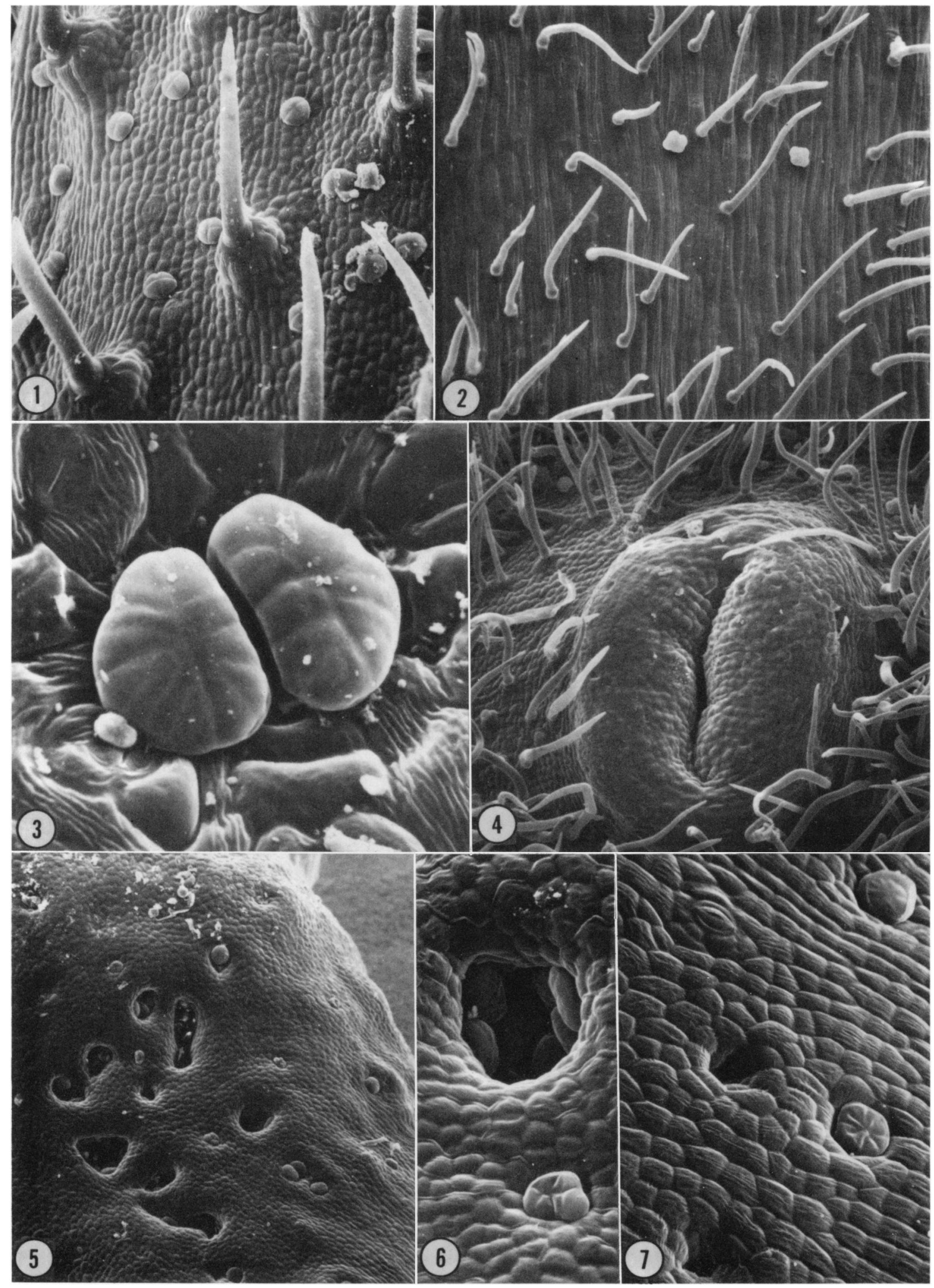



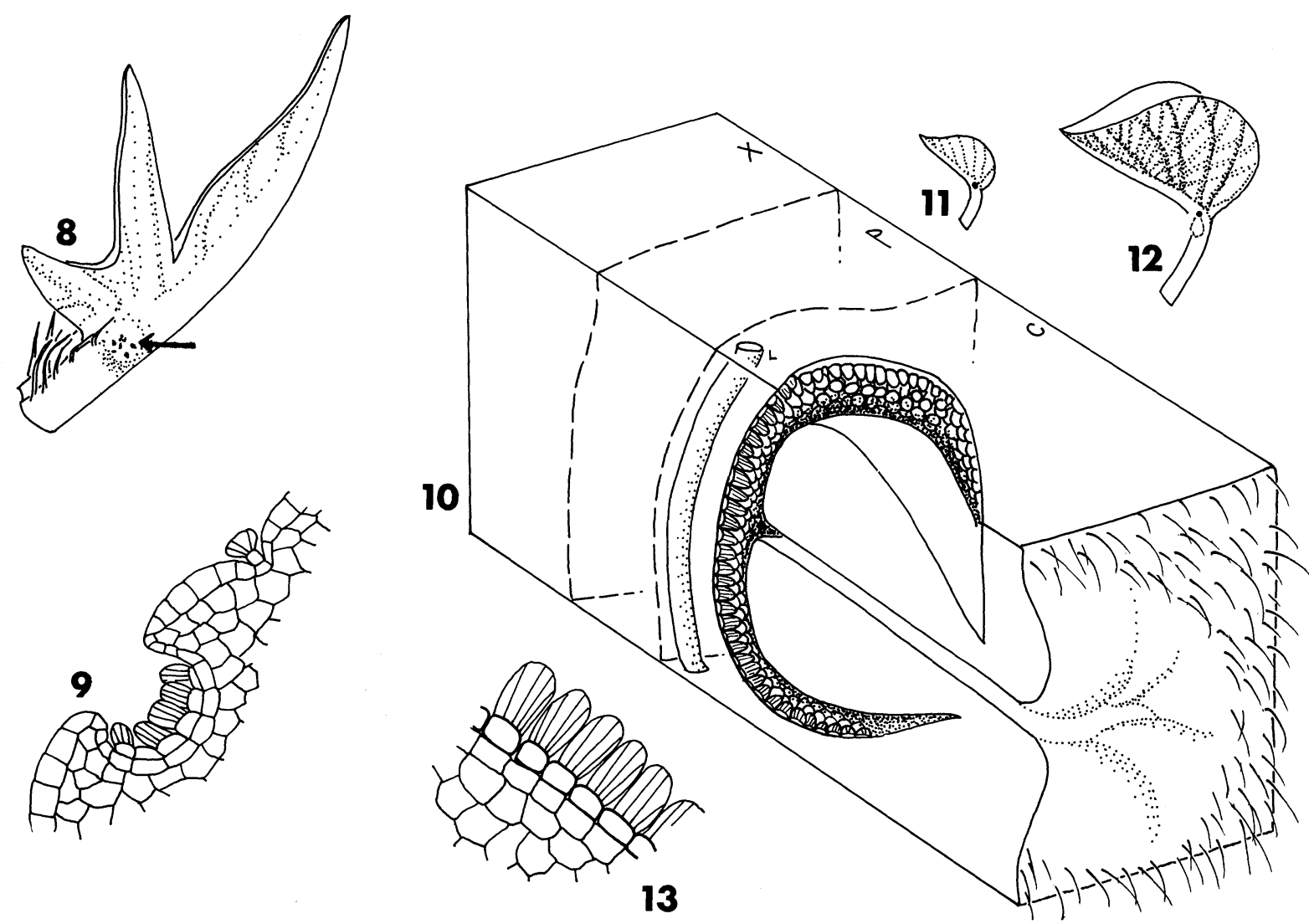

Fig. 8-13. 8. Young leaf of $I$. batatas showing location of basin nectaries on petiole. $\times 3.5$. 9. Cross section through basin nectary of $I$. batatas showing capitate nectar-secreting trichomes. $\times 170$. 10. Cut-away section of crypt nectary of $I$. carnea. Concealed chamber filled with nectar-secreting trichomes is connected to the surface by a duct. $\times 32$. C, cortex; L, laticifer; P, phloem; X, xylem. 11, 12. Young leaves of $I$. carnea showing position of crypt nectary and indicating nectar production. $\times 0.7$. 13. Cross section through capitate nectar-secreting trichomes found on the floor of the crypt nectary of I. carnea. $\times 530$.

to the orifice from the expanded cortical chamber, which is lined with closely-packed, multicellular, nectar-secreting trichomes much like those described for I. batatas (Fig. 13). The locule of the chamber is mostly filled by large, irregular lobes of cortical tissue which are largely devoid of secretory trichomes. The nectary of $I$. carnea is located adjacent to the primary phloem, and there is usually a laticifer between the chamber and the phloem (Fig. 10), which is somewhat displaced inwardly by the nectary.

The petiolar nectaries of $I$. carnea were briefly described by Nieuwenhuis (1907) and Leal (1974), the latter using I. fistulosa Mart. ex Choisy, a synonym of $I$. carnea according to Austin (1977a). Ewart (1895) showed a similar anatomy for I. paniculata (I. mauritiana), and comparably complex petiolar nectaries are mentioned for I. bonariensis by Rao (1930). Spegazzini (1923) described the petiolar nectaries of $I$. fistulosa (I. carnea according to Austin, 1977a), but his drawing differs from material seen by us in several respects, including vascularization and distribution of the secretory trichomes.

The distribution of petiolar nectaries in relation to other plant characteristics was considered. Table 2 shows the distribution of annual and perennial, temperate, and tropical species in our sample. "Tropical" was defined to include subtropical species. Presence of petiolar nectaries on the species is indicated with an asterisk (*). Plants reported from the literature are included. In our samples most perennials have petiolar nectaries and most annuals lack them $\left(\chi^{2}=5.00, P \simeq 0.025\right.$, d.f. $\left.=1\right)$. There is no obvious temperate/tropical pattern $\left(\chi^{2}=3.03, P>\right.$ 0.05 , d.f. $=1$ ), although clearly the majority of species are tropical.

Discussion-Zimmermann (1932), summarizing the literature, reported crypt nectaries (Hohlnektarien) from only five plant families (Leguminosae, Loganiaceae, Malvaceae, Marcgraviaceae and Polygalaceae) in addition to the 
Convolvulaceae. He reported extrafloral nectaries of simpler structure from some 70 vascular plant families. Since Zimmermann's work, a number of families and numerous genera and species have been observed to have EFNs (Schnell, Cusset and Quenum, 1963; Bentley, 1977a; Elias, 1979), but apparently no additional crypt nectaries have been reported.

In addition to being structurally more complex that other EFNs, crypt nectaries are also more complex than most floral nectaries, most of which are morphologically simple (Schmid, 1979). Thus crypt nectaries, such as those in $I p$ omoea, are the most complex extrafloral nectaries known.

The series of morphological types from superficial nectaries to basin nectaries to crypt nectaries, although it does not precisely parallel phylogenetic schemes for the genus, suggests elaboration, in different species, of the hairs shared by all members of the genus. Ewart (1895) suggested homology of the superficial capitate trichomes with the secretory trichomes in the nectaries, which our observations support.

The 3 species known to have petiolar crypt nectaries, I. bonariensis, I. carnea and I. mauritiana, are all placed in section Eriospermum by Austin (1975). Species with basin nectaries (e.g., I. alba, I. batatas and I. pes-caprae) are scattered throughout the genus (Table 1). Present data support some phylogenetically based similarities with respect to EFNs, but at the same time there appears to be considerable convergence. However, most of the sections of Ipomoea are admittedly unnatural, at least in part (Shinners, 1970; Gunn, 1972; Austin, 1975, $1977 \mathrm{~b}$ ), so that detailed phylogenetic analysis is impossible at this time.

In our sample, different species of two of the most ecologically specialized sections, Calonyction (nocturnally flowering, moth-pollinated species) and Quamoclit (diurnally flowering, hummingbird-pollinated species), respectively have and lack petiolar nectaries (Table 1), suggesting that petiolar nectaries are not correlated with either obvious specialization or lack of specialization in this genus.

The case of I. leptophylla is an unusual one. This species has the northernmost range of a perennial North American Ipomoea (to South Dakota and Montana). Nectaries are present only on the first leaves of the season. Furthermore, these nectaries lie on the underside of the lamina, not on the petiole. The site appears to be homologous to the distal end of the petiole where foliar nectaries are found in other species; the petiole of $I$. leptophylla is much reduced. These features may represent adaptations to its xeric habitat or short growing season.

The increasingly recessed petiolar nectaries of
TABLE 2. Distribution of annuals and perennials, temperate and tropical species among the Ipomoea species studied, with special regard to presence of petiolar nectaries. Presence of petiolar nectaries indicated by*

\begin{tabular}{|c|c|c|}
\hline & Annual & Perennial \\
\hline Temperate & $\begin{array}{l}\text { I. coccinea } \\
\text { I. hederacea } \\
\text { I. lacunosa } \\
\text { I. purpurea }\end{array}$ & $\begin{array}{l}{ }^{*} \text { I. leptophylla } \\
\text { I. pandurata }\end{array}$ \\
\hline Tropical & $\begin{array}{l}\text { I. nil } \\
\text { I. quamoclit } \\
\text { *I. tricolor } \\
\text { *I. triloba }\end{array}$ & $\begin{array}{l}\text { *I. alba } \\
\text { *I. bonariensis }{ }^{\mathrm{a}} \\
\text { *I. batatas } \\
\text { *I. cairica } \\
\text { *I. carnea } \\
\text { *I. horsfalliae }{ }^{\mathrm{a}} \\
\text { *I. indica } \\
\text { *I. macrorhiza } \\
\text { *I. mauritiana } \\
\text { *I. pes-caprae } \\
\text { I. stolonifera } \\
\text { I. tiliacea } \\
\text { *I. trichocarpa } \\
\text { *I. turbinata }\end{array}$ \\
\hline
\end{tabular}

a From literature. See Table 1.

Temperate/tropical, annual/perennial designations according to Austin (1975 and in prep.; Shinners, 1970).

different Ipomoea species, culminating in crypt nectaries, can be interpreted as possibly protecting the secretory trichomes from direct contact with nectar feeders. In I. carnea, damage to the raised mound of the nectary on the petiole, especially from beetles, can be seen on older leaves in the field, but does not extend below the surface. Alternative possible advantages for crypt nectaries include reducing evaporative loss through concealment and increasing the volume of nectar available at any given time beyond that of an exposed nectary.

In our sample, presence of petiolar EFNs in Ipomoea correlates with perennial habit, although it does not correlate with temperate or tropical origin. This suggests an important life history aspect to selection for EFNs. Since the majority of studies to date have indicated that the function of EFNs is to attract insects which contribute to plant defense, the differences in life history should be related to the interaction with ants. Perhaps annuals have insufficient time at a site to profit from ant defense of their tissues. Alternatively, annuals may gain greater fitness from utilizing energy available for seed production rather than for nectar-derived defense, thus selecting against EFNs. Whatever the cause, the pattern is consistent with the results of Roughgarden (1975) who, in a model of symbiosis and mutualism, suggested that long-lived members of a taxon should enter into symbioses and mutualisms more frequently than short-lived members, simply because the costs and risks of es- 
tablishing the interaction are more likely to be offset by a long period of interaction after encounter than by a short one.

The lack of correlation with tropical environments is interesting in light of results indicating EFNs are generally more common in tropical than temperate habitats (Zimmermann, 1932; Schnell et al., 1963; Gilbert, quoted in Orians, 1974; Bentley, 1977a; Keeler, 1979). This would suggest that the tendency for plants with EFNs to be tropical is a function of conditions in the particular ecosystems considered, rather than of some parameter shared in a region.

It must be noted that a few of these plants have sepal nectaries although they lack petiolar nectaries. Thus all remarks for phylogeny and distribution made here apply only to presence of petiolar nectaries in Ipomoea. Further generalization at this point is highly speculative and work on sepal nectaries is in progress.

\section{LITERATURE CITED}

Austin, D. F. 1975. Convolvulaceae. In R. E. Woodson and R. W. Shery [eds], Flora of Panama. Ann. Mo. Bot. Gard. 62: 157-224.

-1977a. Ipomoea carnea Jacq. vs. Ipomoea fistulosa Mart. ex Choisy. Taxon 26: 235-238.

. 1977b. Realignment of the species placed in Exogonium (Convolvulaceae). Ann. Mo. Bot. Gard. 64: 330339.

Bentley, B. L. 1976. Plants bearing extrafloral nectaries and the associated ant community: interhabitat differences in the reduction of herbivore damage. Ecology 57: 815-820.

- 1977a. Extrafloral nectaries and protection by pugnacious bodyguards. Annu. Rev. Ecol. Syst. 8: 407-428.

- 1977b. The protective function of ants visiting the extrafloral nectaries of Bixa orellana (Bixaceae). J. Ecol. 65: $27-38$.

Elias, T. S. 1979. Extrafloral nectaries-their structure, distribution and evolution. In T. S. Elias and B. L. Bentley, [eds.], The biology of nectaries. Academic Press, New York. In press.

$\longrightarrow$, and H. Gelband. 1975. Nectar: its production and function in trumpet creeper. Science 189: 289-90.

EWART, M. F. 1895. On the leaf-glands of Ipomoea paniculata. Ann. Bot. (London) 9: 275-288.

Gardiner, W. 1887. On the petiolar glands of the Ipomoeas. Proc. Camb. Philos. Soc. 6: 83.

Gleason, H. A. 1963. The new Britton and Brown illustrated flora of the northeastern United States and adjacent Canada. N.Y. Bot. Garden, N.Y.

GunN, C. A. 1972. Moonflowers: Ipomoea section Calonyction of temperate North America. Brittonia 24: 150168.

House, H. D. 1908. The North American species of the genus Ipomoea. Ann. N.Y. Acad. Sci. 18: 181-263.

INOUYE, D. W., AND O. R. TAYlor. 1979. A temperate region plant-ant-seed predator system: consequences of extrafloral nectar secretion by Helianthella quinquenervis. Ecology. 60: 1-7.

KeELeR, K. H. 1977. The extrafloral nectaries of Ipomoea carnea (Convolvulaceae). Amer. J. Bot. 64: 1182-1188.

. 1979. Frequency of extrafloral nectaries and ants at two elevations in Jamaica. Biotropica. In press.

In press. The extrafloral nectaries of Ipomoea leptophylla (Convolvulaceae). Amer. J. Bot.

LEAL, N. M. 1974. Caracteristicas anatômicas de Ipomoea fistulosa Mart. Boletim do Inst. Biol. da Bahia, Salvador 13: $107-126$.

Matuda, E. 1964. El genero Ipomoea en Mexico. Ann. Inst. Biol. Mex. 35: 45-71.

NAPP-ZINN, K. 1973. Anatomie des Blattes. II. Blattanatomie der Angiospermen. In K. Linsbauer, Handbuch der Pflanzenanatomie. 2 Aufl. Bd. 8,Teil 1. 2A. p. 412425. Gebrüder Borntraeger, Berlin.

NIEWENHUIS VON ÜXKÜLL-GÜLDEBANDT, M. 1907. Extraflorale Zuckerausscheidungen und Ameisenschutz. Ann. Jard. Bot. Buitenzorg 21: 195-328.

O'Donell, C. A. 1959a. Convolvulaceaes Argentinas. Lilloa 29: $87-348$. 376.

. 1959c. Las especies Americanas de Ipomoea L. sect. Quamoclit (Moench.) Griseb. Lilloa 29: 19-86.

. 1960. Notas sobre Convolvulaceas Americanas. Lilloa 30: 39-69.

OrIans, G. 1974. Tropical pollination ecology. In E. R. G Farnworth and F. B. Golley [eds.], Fragile ecosystems. Evaluation of research and applications in the neotropics, p. 5-66. Springer-Verlag, Heidelberg.

PicketT, C. H., aNd W. Clark. 1979. Function of extrafloral nectaries in Opuntia acanthocarpa (Cactaceae). Amer. J. Bot. 66: 618-625.

PIJL, L. VAN DER. 1954. Xylocopa and flowers in the tropics. Proc. K. Ned. Akad. Wet. Ser. C, 57: 413-423, 541-562.

Poulsen, V. A. 1877. Das extraflorale Nectarium bei $\mathrm{Ba}$ tatas edulis. Bot. Ztg. 35: 780-782.

RAO, L. N. 1930. Petiolar glands of the genus Ipomoea. Proc. 17 Indian Sci. Congr. 295.

Roughgarden, J. 1975. Evolution of marine symbiosis-a simple cost-benefit model. Ecology 56: 1201-1208.

Schemske, D. W. 1978. A coevolved triad: Costus woodsonii (Zingiberaceae), its dipteran seed predator and ant mutualists. Bull. Ecol. Soc. Amer. 59; 89.

SchMid, R. 1979. Morphology, anatomy and evolution of septal nectaries. In T. S. Elias and B. L. Bentley [eds.] The biology of nectaries. In press. Academic Press, New York.

Schnell, R., G. Cusset, And M. Quenum. 1963. Contribution a l'étude des glandes extra-florales chez quelques groupes des plantes tropicales. Rev. Gén. Bot. 70: 269341.

Shinners, L. H. 1970. Convolvulaceae. In D. S. Correll and M. C. Johnston [eds.], Manual of the vascular plants of Texas. Texas Research Foundation, Renner, Texas.

Spegazzini, C. 1923. Fitoadénomas. Physis (Buenos Aires) 6: 325-327.

Tilman, D. 1978. Cherries, ants, and tent caterpillars: timing of nectar production in relation to susceptibility of caterpillars to ant predation. Ecology 59: 686-692.

ZIMMERMANN, J. 1932. Über die extraflorale Nectarien der Angiospermen. Bot. Centr. Beih. 49: 99-196. 